Institute of $\mathbf{F}_{\text {ood and }} \mathbf{A}_{\text {gricultural }} \mathbf{S}_{\text {ciences }}$

\title{
Shipping Cattle, Not Tropical Soda Apple Seed ${ }^{1}$
}

Jeff Mullahey and Pat Hogue ${ }^{2}$

Throughout the year, Florida cattlemen ship cows and calves to other states. During the summer season, Florida producers will begin shipping beef calves out of the state. Unfortunately, when cattle are shipped, other items such as weed seed (i.e., tropical soda apple) in the animals' digestive tract also can be moved out of the state. Other southern states are discussing how to restrict the movement of Florida cattle infested with tropical soda apple (TSA) seed.

Tropical soda apple is the invasive weed in improved pastures that is threatening the Florida cattle industry. Current estimates of TSA presence in Florida from all land uses is over 1.0 million acres, and this invasive weed continues to spread to new pastures and ranches within Florida. Currently, TSA has spread as far north as Pennsylvania and west to Mississippi. Movement of TSA into Georgia and South Carolina is primarily linked to the sale of cull cows from Florida. In Mississippi, movement of TSA is associated with Florida feeder calves. In general, TSA seed can spread through cattle, wildlife, hay, grass seed, and sod.

How can the movement of TSA seed in Florida cattle to other states be stopped? The solution requires all cattle operators (small and large herd owners) to voluntarily adopt best management practices developed by the University of Florida, Institute of Food and Agricultural Sciences. If every cattle operator adopts these practices we can avoid having our cattle quarantined before they are shipped out of Florida.

What steps can a producer take to stop the spread of TSA? First, when shipping cattle, ship cattle from an area that does not have TSA or is TSA fruit free. Mowing a TSA infested pasture prior to shipping will eliminate the fruit and the consumption of TSA seed by the cattle. The TSA seed can remain viable in the digestive tract for up to six days. When you receive a group of calves or cows on your ranch, hold them in one area for up to six days to avoid the spread of TSA to other areas on your ranch. If you buy TSA-infested hay or grass seed, contact the seller and ask him/her to stop selling these products and to control the weed on his/her property.

The BMPs that were developed include the following components: Prevention, Detection, and Control. These three components, the "PDC," are part of a proven integrated weed management program that Florida producers can use to control TSA. Contact your local county extension livestock agent for complete information on the BMPs.

1. This document is WEC 176, one of a series of the Wildlife Ecology and Conservation Department, Florida Cooperative Extension Service, Institute of Food and Agricultural Sciences, University of Florida. Original publication date: May, 2003. Visit the EDIS Web Site at http://edis.ifas.ufl.edu.

2. Jeff Mullahey, Professor and Center Director, West Florida Research and Education Center, Milton; and Patrick J. Hogue, Extension Agent III M.S. Livestock, Okeechobee County; Cooperative Extension Service, Institute of Food and Agricultural Sciences, University of Florida, Gainesville, 32611.

The use of trade names in this publication is solely for the purpose of providing specific information. UF/IFAS does not guarantee or warranty the products named, and references to them in this publication does not signify our approval to the exclusion of other products of suitable composition.

The Institute of Food and Agricultural Sciences is an equal opportunity/affirmative action employer authorized to provide research, educational information and other services only to individuals and institutions that function without regard to race, color, sex, age, handicap, or national origin. For information on obtaining other extension publications, contact your county Cooperative Extension Service office. Florida Cooperative Extension Service/Institute of Food and Agricultural Sciences/University of Florida/Christine Taylor Waddill, Dean. 
With respect to controlling TSA, cattle

producers should utilize mowing and/or herbicides to maintain an area free of TSA fruit. Mowing every 60 days will prevent fruit production and result in some (10-30\% for each mowing) plant mortality. Mowing TSA to a 3-inch stubble height, or as close to this height as possible, is best. Multiple mowings will not eliminate TSA from a pasture. Economical (\$3 dollars per acre) control with herbicides is possible if spot applications (spraying individual plants) are utilized. A $0.5 \%$ Remedy solution with a $0.1 \%$ non-ionic surfactant will result in excellent control. A color marker should be added to the herbicide solution to help identify sprayed plants.

Florida cattle producers have been proactive when it comes to controlling TSA and reducing the spread of this weed within Florida and into other states. In fact, other states have implemented many of Florida's BMPs for controlling TSA. All Florida cattle producers need to continue their efforts at controlling TSA and thus stop the spread of TSA within our state and throughout the southeastern United States.

For related information on tropical soda apple, please refer to Edis documents WEC 177, Management Practices to Control Tropical Soda Apple; and WEC 178, Tropical Soda Apple Making a Comeback. 